\title{
파도타기척수병중
}

\author{
백민렬 정승호 이원우 김기훈 신하영 김승민 \\ 연세대학교 의과대학 신경과학교실
}

\section{Surfer's Myelopathy}

Minyoul Baik, MD, Seong Ho Jeong, MD, Wonwoo Lee, MD, Ki Hoon Kim, MD, Ha Young Shin, MD, Seung Min Kim, MD

Department of Neurology, Yonsei University Colloge of Medicine, Seoul, Korea

\begin{abstract}
Surfer's myelopathy is a rare nontraumatic spinal cord disorder associated with surfing. This study reports three patients with surfer's myelopathy. All patients were young males who were previously healthy and first-time surfers at the onset of their symptoms. They developed the symptoms while surfing or shortly thereafter, presenting with lower back pain followed by an acute myelopathy. Spine magnetic resonance imaging showed T2 hyperintense cord lesion. Since the number of surfers is increasing in Korea, awareness of surfer's myelopathy is necessary for early recognition and proper management.
\end{abstract}

J Korean Neurol Assoc 34(2):145-149, 2016

Key Words: Surfer's myelopathy, Magnetic resonance imaging

건강하고 젊은 사람들에서 파도타기를 처음 배운 이후 발생한 급성 척수병증 9예가 2004년도에 처음 보고된 이후 파도타기척수 병증(surfer's myelopathy)이라는 새로운 질환군이 제기되었다. 파 도타기척수병증은 1) 처음 파도타기를 배우며 2) 오랜 시간 파도타 기보드에 엎드려서 허리를 뒤로 젖힌 자세를 유지하였고 3) 특별한 외상이 없는 공통적인 병력을 보였으며, 다양한 중증도의 허리통 증을 전구증상으로 보이고 이후 점진적으로 양하지의 근력저하, 감 각저하, 대소변장애를 동반하는 특징을 보인다. ${ }^{1,2}$ 척추 자기공명영 상(magnetic resonance imaging, MRI)에서는 흥추부위부터 척수 원뿔까지에 T2강조영상과 확산강조영상(diffusion weighted imaging, DWI)에서 고신호강도를 동반한다. ${ }^{2.4}$ 질병의 발생빈도가 낮아 대규모 연구는 존재하지 않으나 주로 하와이 등의 태평양 일대 휴 양지에서 여러 증례들이 보고되었다. 아직까지 국내에서는 파도타 기 이후 발생한 척수병증이 보고되지 않았다. 이에 저자들은 파도 타기 척수병증 3 예를 경험하여 보고한다.

Received November 5, 2015 Revised December 24, 2015

Accepted December 24, 2015

Address for comrespondence: Ha Young Shin, MD

Department of Neurology, Yonsei University College of Medicine,

50-1 Yonsei-ro, Seodaemun-gu, Seoul 03722, Korea

Tel: +82-2-2228-1611 Fax: +82-2-393-0705

E-mail: hayshin@yuhs.ac

\section{중 례}

\section{증례 1}

건강하였던 30세 남자가 처음으로 파도타기를 배웠다. 파도타기 시작 1 시간 째에 허리통증과 함께 양다리 뒤쪽에 당기는 느낌이 순간적으로 지나갔으나 다리 움직임에는 지장이 없어 파도타기교 육을 총 3 시간 동안 지속하였다. 파도타기가 끝나고 6시간 뒤 계단 을 오르는데 갑자기 양다리의 힘이 풀려서 주저앉았다. 이후 걸을 수는 있으나 뒤뚱거렸고, 소변을 전혀 볼 수가 없었다. 지역병원에 서 시행한 척추MRI에서 흥추 9 번부터 척수원뿔까지의 T2고신호 강도를 보여(Fig. 1A) 급성횡단척수염으로 진단을 받았고 본원으 로 전원되었다. 방문 당시 신경학적결손 정도는 AIS (American Spinal Injury Association Impairment Scale) $\mathrm{D}$ 로 다리의 근력이 저하되었으나 저항에는 이길 수 있는 정도였다. 뒷꿈치로 걷기와 앉았다 일어나기 수행에 제한이 있었다. 바빈스키징후 및 발목간 대는 관찰되지 않았으며 양다리 심부건반사는 정상이었다. 뇌척수 액검사와 시각유발전위검사는 정상이었다. 고용량 스테로이드 정 맥 주사를 5 일간 시행 후 퇴원하였으며 2 달 뒤 외래방문 때 환자는 신경학적결손 없이 완전히 회복된 상태였다. 

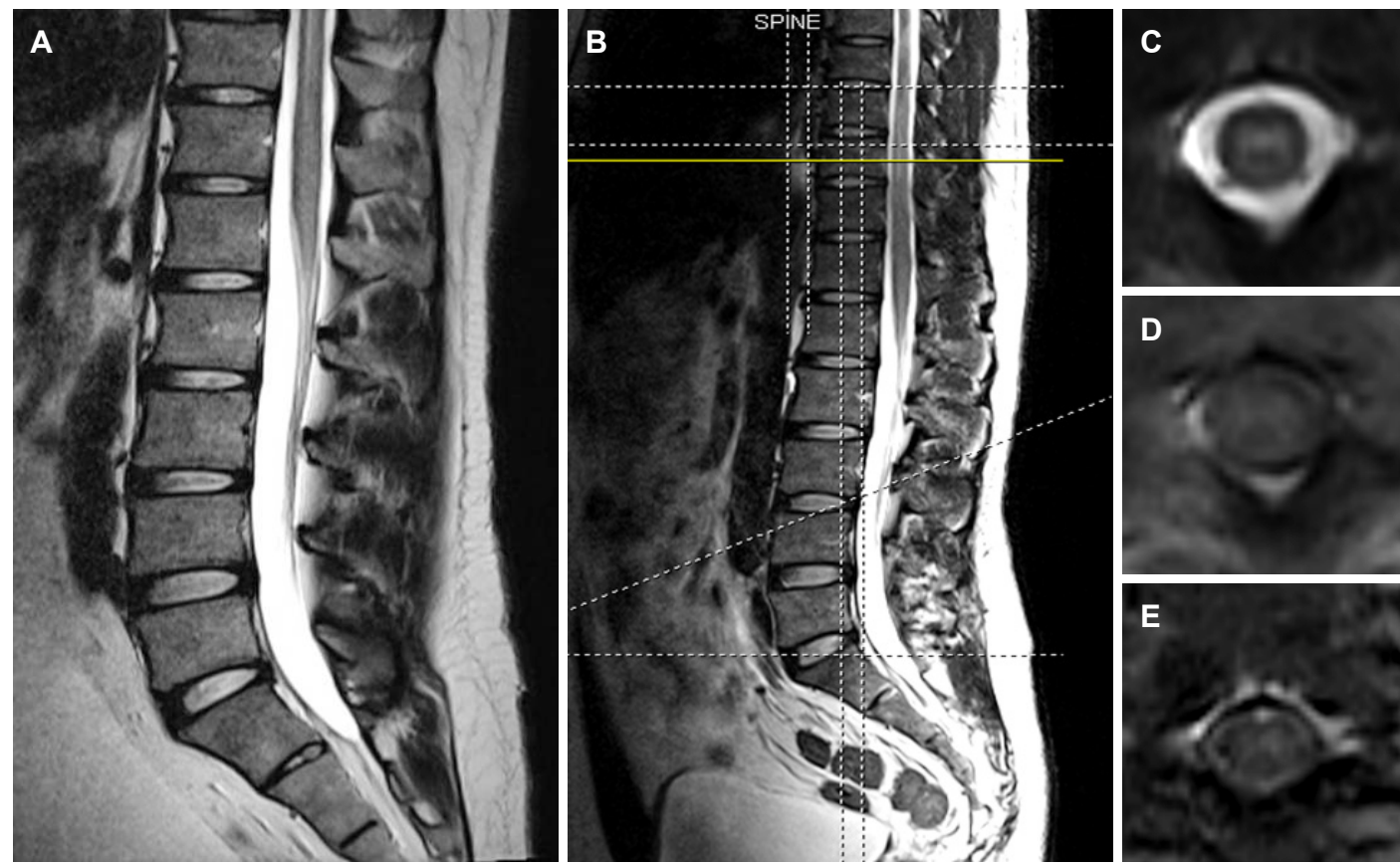

Figure 1. Initial spine MRI of case 1 patient (A) showed T2 hyperintense lesion in the spinal cord extending from the T9 to the conus. Initial spine MRI of case2 patient (B) demonstrates high signal intensity lesion in the spinal cord extending from the T9 to the conus. On the T10 axial section, the MRI shows (C) "pencil-like", central T2 hyperintensity, (D) normal on T1 weighted sequence and (E) no enhancing lesion on T1 weighted sequence with gadolinium enhancement. MRI; magnetic resonance imaging.

\section{증례 2}

경미한 허리추간판탈출증의 과거력 외에는 건강하였던 37세 남 자가 처음으로 2 시간 동안 파도타기를 배웠다. 파도타기가 끝날 무 렵에 허리통증과 양쪽 다리에 저린감이 있었다. 30 분 후 조깅 중 허리통증이 참을 수 없을 정도로 심해지면서 순간적으로 양다리에 힘이 빠져 주저앉았으나 곧 회복되었다. 파도타기를 마치고 2시간 째에 다시 양다리에 힘이 없어져서 전혀 움직일 수가 없는 상태가 5 분 동안 지속되었다. 이후 약간 회복되어 겨우 보행은 가능하였으 나 양다리의 통증이 심하여 잠을 잘 수 없었으며 소변을 전혀 볼 수 없었다. 지역병원에서 이 증상에 대하여 척추MRI를 하였고, 흥 추 9번부터 척수원뿔까지 T2고신호 강도가 관찰되었다(Fig. 1B). 흥추부 10 번 축단면의 $\mathrm{T} 2$ 강조영상에서 척수의 중앙 부위에 연필 심 모양의 고신호 강도를 보였으며(Fig. 1C), T1강조영상은 정상 이었고 조영 증강은 되지 않았다(Fig. 1D-E). 급성횡단척수염을 진 단받고 본원으로 전원되었다. 방문 당시 신경학적결손 정도는 AIS $\mathrm{D}$ 로 왼쪽 다리로 제자리 뛰기, 뒷꿈치로 걷기, 까치발로 걷기에 제한이 있었다. 요추부 5 번 이하로 촉각의 저하가 확인되었으나 위 치와 진동감각은 정상이었다. 양쪽 다리 심부건반사는 정상이었고
바빈스키징후 및 발목간대는 관찰되지 않았다. 뇌척수액검사와 시 신경유발전위검사는 정상이었다. 고용량 스테로이드 정맥 주사를

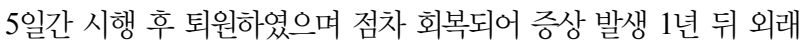
에서 환자는 다리의 경미한 저린감 이외에는 불편함이 없는 상태 였다.

\section{증례 3}

건강하였던 22세 남자가 하와이에 여행 가서 처음으로 파도타 기를 배우던 중 30 분 째에 심한 허리 통증이 발생하여 파도타기를 중단하였다. 30 분 뒤부터 양쪽 다리에 힘이 점차적으로 빠지기 시 작하여 1 시간 뒤에는 전혀 움직일 수가 없었고 대소변도 조절할 수가 없었다. 하와이에서 시행한 척추MRI에서 흥추 7번부터 척수 원뿔까지 T2와 DWI에서 고신호강도가 관찰되어(Fig. 2) 파도타기 척수병증으로 진단받고 추가적인 검사나 치료는 하지 않았다. 증 상이 발생하고 4 일 뒤에 귀국하여 국내 다른 병원에서 척수강 내 스테로이드 주입 치료를 한차례 시행하고 본원 재활의학과로 전원 되었다. 2 달 뒤에 신경과 협진 의뢰되어 시행한 신경학적진찰에서 AIS A로 양다리에서 근육의 수축이 전혀 관찰되지 않았으며, 피부 

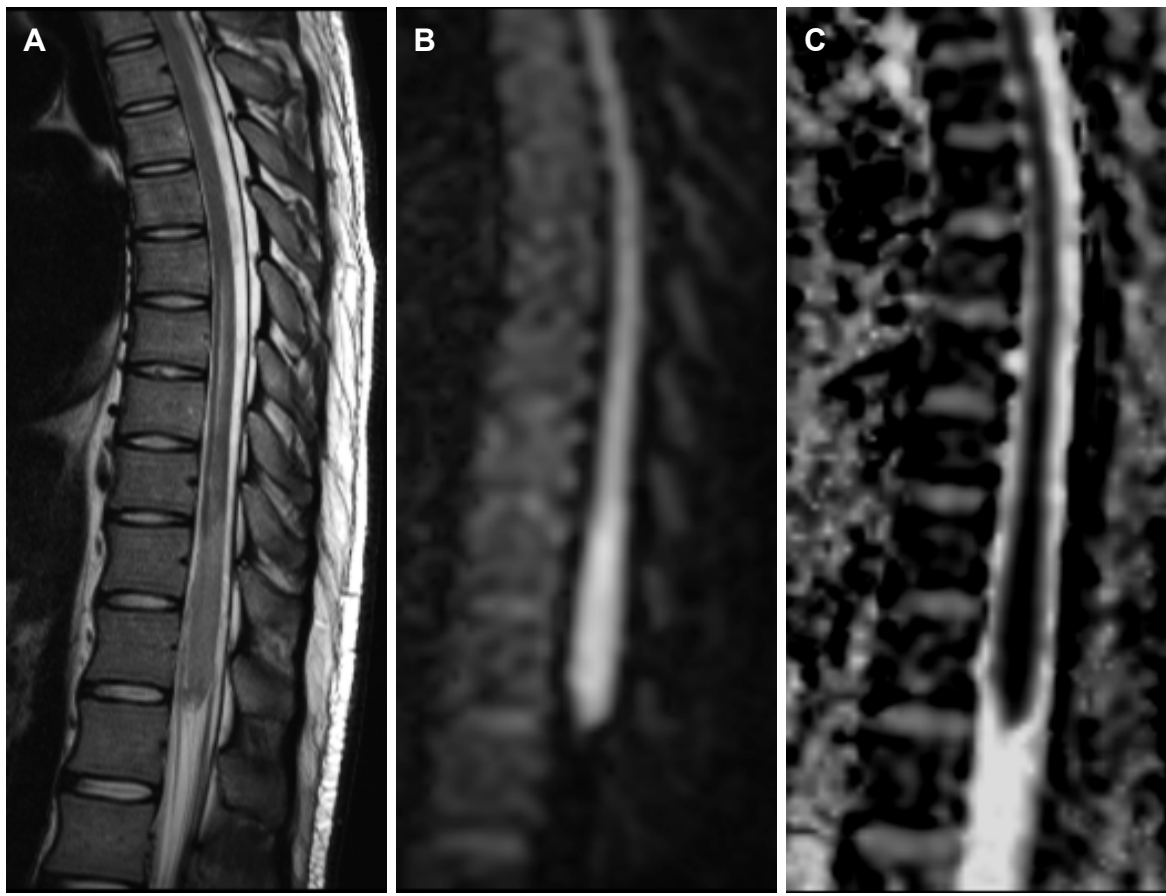

Figure 2. Initial spine MRI of case 3 patient. Sagittal T2-weighted MRI (A) demonstrates high signal intensity lesion in the spinal cord extending from the T7 to the conus. Sagittal (B) diffusion-weighted image and (C) apparent diffusion coefficients shows acute ischemic change. MRI; magnetic resonance imaging.

Table. Summary of patients, clinical findings, and imaging results

\begin{tabular}{|c|c|c|c|}
\hline & Case 1 & Case 2 & Case 3 \\
\hline Sex/age & Male/30 & Male/37 & Male/22 \\
\hline Surfing duration & 3 hours & 2 hours & 30 minutes \\
\hline Surfing place & Gangneung & Jeju island & Hawaii \\
\hline AIS admit & $\mathrm{D}$ & $\mathrm{D}$ & A \\
\hline Prodrome & $\begin{array}{l}1 \text { hour after, back pain and both leg } \\
\text { radiating pain }\end{array}$ & $\begin{array}{l}2 \text { hours after, back pain and both leg } \\
\text { numbness }\end{array}$ & 30 minutes after, back pain \\
\hline Symptom (weakness) onset time & 6 hours after & 6 hours after & 1 hour after \\
\hline Sensory level & S4-5 & L5 & $\mathrm{L} 1$ \\
\hline Urinary difficulty/constipation & $+/-$ & $+/+$ & $+/+$ \\
\hline Initial MAP (mmHg) & $115(2015.8 .405: 49)$ & $83(2014.10 .2907: 00)$ & Not known \\
\hline CSF study & Pr220 R0 W4 Pro48.5 Glc55/96 & Pr170 R7 W2 Pro35.9 Glc 109/118 & Not done \\
\hline MRI time (time after surfing) & 2 days after & 1 day after & 12 hours after \\
\hline DWI & Not done & Not done & $(+)$ \\
\hline $\mathrm{T} 2$ extent & T9-conus medullaris & T9-conus medullaris & T7-conus medullaris \\
\hline Enhancement & Not done & $(-)$ & $(-)$ \\
\hline Treatment modality & $\begin{array}{l}\text { IV methylprednisolone } 1 \mathrm{~g} / \text { day for } \\
5 \text { days }\end{array}$ & $\begin{array}{l}\text { IV methylprednisolone } 1 \mathrm{~g} / \text { day for } \\
5 \text { days }\end{array}$ & Intrathecal steroid injection \\
\hline AIS follow-up & E: 2 months & D: 1 year & A: 2 months \\
\hline
\end{tabular}

AIS; American Spinal Injury Association Impairment Scale, MAP; mean arterial pressure, DWI; diffusion-weighted imaging, Pr; pressure (mmH2O), R; RBC count (cells/uL), W; WBC count (cells/uL), Pro; total protein (mg/dL), Glc; CSF glucose (mg/dL)/serum glucose (mg/dL), T; thoracic, L; lumbar, S; sacral. 
분절 요추부 1 번 이하로 촉각, 위치와 진동 감각이 모두 소실되었 다. 양다리에서 심부건반사, 바빈스키징후와 발목간대는 관찰되지 않았다. 증상 발생 1년 뒤 외래에서 환자는 신경학적 호전 없이 비슷한 상태로 휠체어를 사용하고 있었다.

위에서 기술한 파도타기 척수병증 3 증례들의 임상양상과 검사 를 정리하였다(Table).

\section{고 찰}

파도타기척수병증의 경우 발생 기전이 증명되지는 않았으나 허 리를 뒤로 젖히는 자세와 관련한 척수허혈이 중요한 기전으로 추 정된다. 축방향(axial)에서는 앞척수동맥과 뒤척수동맥의 분수계영 역(watershed zone)인 중앙 부위가 상대적으로 취약해 척추MRI $\mathrm{T} 2$ 강조영상에서 연필심처럼 척수의 중앙 부위로 고신호강도의 병 변을 보인다. 시상면(sagittal)에서 주로 흥추 하부에서 척수원뿔까 지 병변이 생기는 이유는 Adamkiewicz동맥에 가해지는 일과성의 물리적인 압박과 이 혈관의 연축과 연관 있을 것으로 추정된다. 해 당 혈관은 흥추 10 번에서 요추2번 사이에서 기시하여 위쪽으로 주 행해 앞척수동맥과 합쳐져 주로 하부 척수에 혈액 공급을 담당한 다. Adamkiewicz동맥에 경색증이 발생한 환자의 척추MRI 소견이 파도타기 척수병증 환자의 MRI 소견과 유사한 점이 이를 뒷받침 한다. ${ }^{5-7}$

양다리의 근력 저하와 촉각 저하에 비해 상대적으로 위치와 진 동감각의 저하가 경미하거나 전혀 동반되지 않는 감각해리(sensory dissociation)가 관찰되는 증례들이 다수 보고 되었으며, ${ }^{4,8}$ 한 연구 에서는 19 명의 환자 중 6 명에서 이러한 임상양상이 관찰되었다. ${ }^{2}$ 이러한 앞척수동맥증후군과 유사한 경과를 보이는 점이 또한 파 도타기 척수병증의 원인이 허혈성임을 시사한다.

우리가 보고한 증례 2의 환자에서는 감각해리가 관찰되었으나 증례 3 의 환자에서는 감각해리가 관찰되지 않았다. 우리 환자에서 처럼 방문 당시 증상이 심할 경우 감각해리가 관찰되지 않을 가능 성이 있다. 감각해리가 발생하는 유발인자에 대해서는 앞으로 추 가적인 연구가 필요하다.

그 외에도 마른 체격과 탈수상태, 장기간 비행기 등을 이용한 여 행으로 유발된 응고항진상태가 영향을 주었을 것이라는 가설이 있 다. ${ }^{1}$

대부분의 파도타기척수병증은 휴양지에서 발생하고 환자가 바 로 자신이 사는 곳으로 돌아가기 때문에 임상경과 추적에 제한이 있어 장기 예후에 대한 정보가 부족하다. ${ }^{2,3}$ 기존 연구들에서는 일 반적으로 발병초기의 신경계 손상 정도가 심할수록 장기 예후가
좋지 않았고, 척추MRI에서 관찰되는 손상 정도는 예후와 관련이 없는 경향을 보였다. 2,39 우리 환자들에서도 발병 초기에 증상이 경 미하였던 증례 1 과 증례 2 의 경우는 후유증이 거의 없이 회복되었 으나, 증상이 심한 증례 3 의 경우는 발병 초기에 비해 거의 회복되 지 않았다.

현재까지 확립된 치료법은 없으나 우리 증례와 같이 고용량의 스테로이드를 투약을 하는 경우가 많다. 하지만 다리가 완전히 마 비된 한 환자가 6 개월 이상의 재활 치료와 적절한 보장구 사용을 통해 집 안에서는 일상생활이 가능해진 경우가 있어 적극적인 재 활 치료 및 적절한 보장구 사용이 환자의 삶의 질 개선에 도움이 되겠다. 증례 3 의 경우 휠체어 사용과 휠체어 스포츠 등으로 재활 훈련 중에 있다.

우리가 보고한 세 증례들은 모두 이전에 특별한 과거력과 외상 력이 없는 젊은 남자들로 처음 파도타기를 배우며 몸을 뒤로 젖히 는 자세를 취하고 증상이 발생하였다. 또한 척추MRI에서 1) 흥추 부터 척수원뿔까지 2) 중앙 부위에 연필심 모양의 $\mathrm{T} 2$ 고신호강도가 관찰되어 파도타기 척수병증을 시사하는 소견을 보였다. 증례 1과 2 의 경우 뇌척수액검사에서 이상 소견이 관찰되지 않았으며, 증례 3 의 경우 DWI에서 고신호강도가 확인되었다. 특발성척수염을 완 전히 배제할 수는 없지만 위의 임상양상과 MRI를 포함한 검사소 견들을 고려할 때 파도타기척수병증으로 진단하는 것이 합당하겠다. 증례 3 의 경우 파도타기척수병증에 대한 경험이 많은 하와이에 서 발생되었고 하와이 소재 병원에서는 이 환자의 척수병증에 대 해 진료 초기부터 파도타기척수병증을 의심하였고 조기에 진단하 였다. 하지만 국내에서 발병한 증례 1 과 2 는 처음에 급성횡단척수 염으로 진단되었으며 파도타기를 한 병력은 중요하게 다루어지지 않았다. 생활 수준의 향상으로 최근 국내에서도 파도타기를 즐기 는 인구가 점차 증가하고 있으며, 국내 신경과 의사들이 파도타기 이후 발생한 급성척수병증을 접할 기회가 늘어날 것이다. 특별한 과거력이 없는 젊은 사람이 처음 파도타기를 배우면서 오랜 시간 파도타기 보드에 엎드려서 허리를 젖힌 자세를 유지한 이후 특별 한 외상이 없이 척수병증이 발생하였다면 파도타기척수병증을 의 심할 수 있어야 하겠다.

\section{REFERENCES}

1. Thompson TP, Pearce J, Chang G, Madamba J. Surfer's myelopathy. Spine (Phila Pa 1976) 2004;29:E353-E356.

2. Chang CW, Donovan DJ, Liem LK, O'Phelan KH, Green DM, Bassin S, et al. Surfers' myelopathy: a case series of 19 novice surfers with nontraumatic myelopathy. Neurology 2012;79:2171-2176.

3. Nakamoto BK, Siu AM, Hashiba KA, Sinclair BT, Baker BJ, Gerber 
MS, et al. Surfer's myelopathy: a radiologic study of 23 cases. AJNR Am J Neuroradiol 2013;34:2393-2398.

4. Lieske J, Cameron B, Drinkwine B, Goretzke S, Alemi L, Needham K, et al. Surfer's myelopathy-demonstrated by diffusion-weighted magnetic resonance imaging: a case report and literature review. J Comput Assist Tomogr 2011;35:492-494.

5. Kudo K, Terae S, Asano T, Oka M, Kaneko K, Ushikoshi S, et al. Anterior spinal artery and artery of Adamkiewicz detected by using multi-detector row CT. AJNR Am J Neuroradiol 2003;24:13-17.

6. Shamji MF, Maziak DE, Shamji FM, Ginsberg RJ, Pon R. Circulation of the spinal cord: an important consideration for thoracic surgeons.
Ann Thorac Surg 2003;76:315-321

7. Tanaka H, Minatoya $\mathrm{K}$, Matsuda $\mathrm{H}$, Sasaki H, Iba $\mathrm{Y}$, Oda T, et al. Embolism is emerging as a major cause of spinal cord injury after descending and thoracoabdominal aortic repair with a contemporary approach: magnetic resonance findings of spinal cord injury. Interact Cardiovasc Thorac Surg 2014; 19:205-210.

8. Aoki M, Moriizumi S, Toki M, Murakami T, Ishiai S. Rehabilitation and long-term course of nontraumatic myelopathy associated with surfing. Am J Phys Med Rehabil 2013;92:828-832.

9. Aviles-Hernandez I, Garcia-Zozaya I, DeVillasante JM. Nontraumatic myelopathy associated with surfing. J Spinal Cord Med 2007;30:288-293. 